\title{
System of wheat intensification (SWI) - A new approach for increasing wheat yield in small holder farming system
}

\author{
Lalita Rana $^{1}$, Hirak Banerjee ${ }^{2}$, Krishnendu Ray $^{3}$ and Sukamal Sarkar ${ }^{1^{*}}$ \\ ${ }^{1}$ Department of Agronomy, Bidhan Chandra Krishi Viswavidyalaya, Mohanpur-741252 (West Bengal), INDIA \\ ${ }^{2}$ Regional Research Station (CSZ), Bidhan Chandra Krishi Viswavidyalaya, Kakdwip-743347, (West Bengal), \\ INDIA \\ ${ }^{3}$ Sasya Shyamala Krishi Vigyan Kendra, Ramakrishna Mission Vivekananda University, Narendrapur-700103 \\ (Kolkata), INDIA \\ *Corresponding author. E-mail: sukamalsarkarc@yahoo.com \\ Received: October 18, 2016; Revised received: February 27, 2017; Accepted: July 22, 2017
}

\begin{abstract}
Given the confluence of water scarcity, declining area under wheat and continuing increase in population, raising wheat productivity has become a serious concern to the wheat scientists. Yield contribution from irrigation is more significant in wheat. Increase in the irrigation management levels for wheat is probably more relevant and easier to improve water productivity. But transplanted wheat seems high water requiring and economically less feasible. Seedlings have usually poor survival rate, and are often more fragile than rice seedlings at the two leaves stage. Besides plants do not grow quickly and vigorously, and show a delay in development compared to the direct seeding treatment. All yield parameters are often lower compared to the direct seeding treatment due to transplanting of aged seedlings, greater shock of transplantation, high plant density, improper amount and timing of water deliveries. Therefore, applying SRI (system of rice intensification) practices is expected to have a positive impact on the wheat plants, similar to the impact on rice. SWI is a new concept and goes with the SRI principle. It can reduce weeding time to one-third and to one-half of the time needed for current weeding practice. Herbicide use is effective with SWI, but farmers are inventing or modifying tools that reduce the labour time required for weeding. Thus, SWI is a methodology aimed at increasing the yield of wheat, where all agronomic principles are put into practices to provide high wheat yield per drop of water and per $\mathrm{kg}$ of agricultural inputs like fertilizer, seed etc.
\end{abstract}

Keywords: Nutrient, System of intensification, Water, Wheat, Yield

\section{INTRODUCTION}

Wheat stands second in grain production in the world and most widely cultivated food crop (Meena and Singh, 2013). The Global area of wheat cultivation was $218.5 \mathrm{~m}$ ha compared to $156 \mathrm{~m}$ ha under rice (FAO, 2014). The rankings of top 10 countries in the world for total area, production and yield of wheat are shown in Table 1. In India, wheat is second important staple food crop (DWR, 2012) after rice. India has now become the second largest producer of wheat in the world with a production of $93.5 \mathrm{~m} \mathrm{t}(13.6 \%$ of total world wheat production) from $29.7 \mathrm{~m}$ ha area with average productivity of $3.15 \mathrm{t} / \mathrm{ha}$ (FAO, 2014). Wheat production has steadily increased in India from 195253 through 2012-13 (FAI, 2014). Wheat acreage was quite stable since 1952-53, except for a small increase since 2007-08 (Fig. 1). The major wheat producing states are Uttar Pradesh, Punjab, Haryana, Madhya Pradesh, Rajasthan, Bihar, Maharashtra, Gujarat, West Bengal and Uttarakhand (Fig. 2), and together these states contribute about $98 \%$ of national wheat production (DES, 2014). In general, the wheat acreage is very low in states with very short winter season (90 days or less) such as West Bengal, Odisha, Andhra Pradesh and some other states of southern India. At maturity, the crop requires mild temperature, but in those areas terminal heat stress occurs at the time of maturity which reduces duration of grain development and consequently the grain yield (Mukherjee, 2012). Although direct seeding is the common practice in wheat cultivation, but seedling transplanting has been adopted in some areas of India where agricultural labour force is excessive and inexpensive. Earlier, transplanting of wheat seedlings was just done to fill the germination gaps, especially late in winter when the soil temperature would not support the seed germination. Later it was found that in the fertile lands, transplanted wheat plants can generate higher quantity of active branch roots, thereby the physiological activities was enhanced with the obvious consequence of increased grain yield (Xu et al., 2011). However, the objective of the review work in this paper was to compile experimental and theoretical results, finally draw a conclusion whether the SWI did increase yield potential of wheat crop to an extraordinary degree. 


\section{SYSTEM OF WHEAT INTENSIFICATION (SWI)}

Food requirement of India is increasing with ever increasing population. Indian agriculture must continuously evolve to remain ever responsive to meet the food requirement, and to meet the growing and diversified needs of different stakeholders in the entire production to consumption chain. In order to capitalize on the opportunities and to convert weaknesses into opportunities, there is a need to intensify the cultivation of crops by using optimum input through BMP (Best Management Practices) for resource conservation (Mishra et al., 2007). Wheat intensification is a new concept and goes with the system of rice intensification (SRI) principle. In case of SWI, all agronomic principles of SRI are put into practices and integrated with package of practices of wheat crop.

About SWI: The technology which has high potentiality to provide high wheat yield per drop of water and per kg of agricultural inputs (fertilizer, seed etc.) and application of other SRI principle to wheat crop, is known as system of wheat intensification (Dhar et al., 2014). Adoption of this technology can increase the productivity of wheat by more than 2 times (Uphoff et al., 2011). Lead SRI researchers (Sheehy et al., 2004) are spearheading new research on applying SRI methods to wheat cultivation in China and Madagascar (Table 2).

The methodology, dubbed as system of wheat intensification (SWI) has improved wheat yields for smallscale farmers in India, while reducing input costs and labour. Evidence is accumulating that once farmers become more comfortable and skilled with the new methods, SWI can become labour saving with infrastructural support, particularly farm mechanization (Satyanarayana et al., 2007). Engagement of labour can be reduced with the use of seed driller and conoweeder instead of tedious line sowing and manual weeding, respectively. The time required for plot preparation, planting and to cover seeds with soil is almost half to that of conventional plots, resulting it less labour-intensive method. For irrigation, intermittent wetting and drying method will save labour significantly instead of maintaining water at field situations under conventional practice. And for these reasons, farmers ranked labour-saving as the greatest attraction of SWI, more than its water-saving, and more than its increases in yield and profitability ( $\mathrm{Li}$ et al., 2005). It has been reported that Indian farmers improved wheat yields by 2 and 3 times higher than those from conventional methods (Dhar et al., 2014). SWI practices have spread quickly in India including Bihar, Chattisgarh, Madhya Pradesh, Odisha, Punjab and Uttar Pradesh, where farmers have spontaneously begun applying the principles to other crops, such as millet, mustard, soybean, eggplant, and maize. Collectively, these practic- es are becoming known as system of crop intensification (Styglinger, 2011). Difference between traditional wheat cultivation and SWI technology has given in Table 3 (Suryawanshi et al., 2012).

Historical background: During 2009, 400 farmers in India (mostly illiterate and landless women) used SWI (Uphoff et al., 2011). In an unprecedented manner, the number of SWI farmers has been increased to about 2 lakhs till date because of the fact that the methodology is well-suited to the needs of small-scale farmers in India, and making big improvements to the food security of farming families. The most excitement through SWI is being generated among the farmers of Bihar who say that with SRI in the summer and SWI in the winter, they have gone from producing three months' supply of food for their families to 6-7 months (Uphoff et al., 2011).

The method is about managing the crop, soil and nutrients to promote a vibrant soil system that, in turn, promotes larger root systems. With adequate spacing and loose soil, the roots of the crop can grow deeper than conventional cropping methods. Compost is used instead of chemical fertilizer to maintain soil health. Moreover, irrigation of the field synchronized with the weeding operations in the early stages of crop growth made the soil more friable (Dhar et al., 2015). Weeding wheat fields with rotary hoe or cono-weeders helps by churning the soil and incorporating the weed biomass as it aerate the root zone. This encourages aerobic microorganisms to proliferate and promotes healthy soil (Sinha and Talati, 2007). The extra root activity saves the soil from compacting (Uphoff et al., 2011). By using fewer plants, each plant is hardier and can grow to its natural potential. The only extra thing is addition of organic matter. By adding plenty of organic matter to the soil, one can get a lot more bacteria, fungi, mites and earthworms which make the soil well-aerated by allowing more air and water to penetrate, and thereby allowing better root growth.

A big part of the success of SWI comes from the roots of the crops. More fully developed root systems make crops more resilient in times of drought, because the plant can access moisture deeper in the soil. This could be important for coping with climate change. In terms of drought resistance, having deep roots that are tapping residual soil moisture are really critical for getting plants through the heat stress (Uphoff et al., 2011).

The interesting thing about this method is that it reverses the way that agricultural technology is developed, with comparatively 80-90, 30, 10 and 30\% less seed, chemical fertilizer, irrigation water and production cost, respectively (Styger and Ibrahim, 2009). With SWI, we share the principles of how to adjust the management of the plant with the farmer. Then the farmer adopted by adjusting it to his own field and labour conditions, and finally the farmer is one who becomes the expert. Decades of input-intensive farm- 
ing and agricultural policy have caused many farmers to forget the complex knowledge and practices regarding their crop and soils that they otherwise would have used. Farmers got weaned of their earlier fertility management practices by the convenience of fertilizer, and often with the help of heavy government subsidies. Farmers have been persuaded that chemical fertilizer is superior to their compost (Uphoff, 2006). He explains further that SWI go against conventional logic. It is counter intuitive to think that by cutting plant population by $80-90 \%$, cutting water inputs by $70 \%$ (by practicing alternate wetting and drying throughout the crop cycle with no continuous flooding) and reducing fertilizer inputs, one can get higher yield. The other reasons for higher yield under SWI could be related to the resistance to abiotic stresses, less economic risk and higher milling outturn (Satyanarayana et al., 2007).

However, it is to be remembered that application of organic manure can increase the nutrient availability in the soil. According to Johnston (1994) long term regular FYM application may increase the quantity of mineralizable nitrogen in soils considerably; but those nutrients need to be replenished using inorganic source of fertilizers to reduce the mining of nutrients from soil and make the production system sustainable for longer period. Therefore, we do not discourage the use of improved seeds and some amount of chemical fertilizer, as long as it is coupled with organic fertilizer. The key is to pay closer attention to what is happening below the ground with roots and soils. The principles are a more knowledge-based system, and the farmer has more control (Styger and Ibrahim, 2009).

Principles of SWI: SWI is primarily based on two principles of crop production.

Principle of root development: Root development is the first step of healthy growth and development of any plant. In the traditional wheat cultivation method, when seeds are sown in a closer spacing, their roots must compete with each other for nutrients, water and sunlight. Competition with weeds is also common due to more weed population (Kaur et al., 2012). The closer spacing promotes the inhibition of root growth, and as a result the wheat crop fails to suppress the growth of emerging weeds in the field. Their root system is not so developed, and the effect was evident on tillering capacity (decreased by $41.6 \%$ ) and biomass yield (60-65\% loss) in Lahore (Pakistan), as reported by Anjuman and Bajwa (2010). But in the case of SWI, plants are spaced wide $(20 \mathrm{~cm}$ from each other) and mostly in a square pattern. As SWI practice improve the soil over time, wider spacing $(20 \mathrm{~cm} \times 20 \mathrm{~cm})$ can later give even higher yields. Sparse panting avoids the inhibition of root growth that results from crowding. And by exposing plants to more light and air, SWI creates the edge effect (border effect) for the whole field. Planting in a square pattern allows farmers to weed their fields in perpendicular directions, which achieves more and better soil aeration (Satyanarayana et al., 2007). Further, a healthy stand of wheat that has a head start on weeds is competitive and will suppress weed growth (Kaur et al., 2012). When the wheat plants are set out far from each other, and if the soil conditions are good, their roots will have plenty of space to spread out, thereby not competing with each other. So the wheat plant produces not only more number of tillers but a high volume of root due to more access to both oxygen and water under aerobic condition. SWI is characterized by soil-water and solar radiation regimes that are essentially different from those of conventional wheat cultivation, and this cultivation change may affect the structure and functioning of soil biota, nutrient status and cycling and root system due to aerobic soil condition with SWI practices. Similar results were demonstrated by Singh et al. (2012) while growing rice by system of rice intensification in Coimbatore (Tamil Nadu).

Principle of intensive care: Major detriments to higher productivity of wheat are stiff competition from weeds, multiple nutrient deficiencies, insects-pests and incidence of diseases (Kaur et al., 2012). Therefore, to enhance productivity it requires intensive care in every stage of plant growth especially with respect to management of organic manure, irrigation, weed, insect and disease.

The following core principles of SRI developed for rice (Dobermann, 2004; McDonald et al., 2006) are being applied in SWI method of cultivation.

i) Priming of seeds with seed selection/treatment.

ii) Wide and uniform spacing of single plants set out in a square pattern in the field (starting at $20 \mathrm{~cm} \times 20 \mathrm{~cm}$, but going upto $50 \mathrm{~cm} \times 50 \mathrm{~cm}$ ).

iii) Suppressing weeds mechanically rather than chemically or by hand to increase aerating of the soil by 2 or 3 times.

The other practices in crop husbandry are similar to those used with the usual methods of wheat cultivation. Khadka (2013) concluded that the wheat (cv. WK 1204) yields achieved by applying SRI principles (careful transplanting of 8-12 days old seedlings at wider spacing; intermittent irrigation for keeping the soil moist to the point of surface cracking; weeding is started about 10 DAT, with at least 2 weeding; compost is used instead of chemical fertilizer) are at least double those achieved with conventional methods in Dadeldhura, Baitadi and Doti districts of Nepal as well as Himachal Pradesh state of India.

Why SWI is needed? The SWI is an adaptation of techniques used in the SRI. SRI has been successfully practiced in 35 countries worldwide. In terms of agricultural productivity, the sustainability of the farming system is an important issue. More than 10 million hectare under rice-wheat cropping system in North India is one of the most intensively cultivated areas in the world, which is possible only through the use of 
more intensive inputs like seeds, chemical fertilizers, herbicides, plant protection chemicals etc. Imbalanced use of external inputs particularly agro-chemicals (fertilizer, fungicides, pesticides, herbicides) might cause deleterious effect on the soil and environment, as well as on the system productivity. Moreover, intensive tillage and burning of crop residues especially rice and to some extent wheat in the north-western plains has led to the depletion of soil organic carbon, a direct indicator of sustainability of soil resource (Gupta et al., 2011). Further, the declining response to inputs has been perceived to be the major challenge for the sustainability of wheat-based cropping systems across the Indo-Gangetic plain. In addition, the effect of climate change needs to be addressed to enhance or at least maintain the productivity at lower production costs. SWI could be a viable option to address the following issues of present day agriculture.

Soil degradation: The intensive tillage coupled with crop residue burning and continuous mining of soil has led to the depletion of soil organic matter as well as essential plant nutrients. The situation is further complicated by imbalanced fertilization leading to expression of multiple nutrient deficiencies, decline in soil fertility and ultimately results in higher cost of production (Choudhary and Behera, 2013). Dutta et al. (2015) also opined that continuous mining of soil has started showing farming systems fatigue in the form of multiple nutritional deficiencies. Zinc is already recommended as it is estimated that $50 \%$ Indian soil are now zinc deficient (Kabeya and Shankar, 2013) and there are more frequent occurrence of deficiencies of $\mathrm{Mn}$, $\mathrm{Fe}, \mathrm{Cu}, \mathrm{Mo}$ and $\mathrm{B}$ in the rice-wheat system. More than $35 \%$ soils are also deficient in $\mathrm{S}$ and $\mathrm{K}$ status has also reached a threshold in many soils since farmers are mainly applying nitrogen and phosphorus to the crops. Strategies like residue management, use of improved farm machinery, green manuring and balanced use of fertilizers through the concept of 4R Nutrient Stewardship (that defines right source, rate, time and place for plant nutrient application as those producing the economic, social, and environmental outcomes desired by all stakeholders to the soil-plant eco-system) in SWI could be beneficial in this context.

Lack of good quality irrigation water: The indiscriminate use of water (especially ground water) has led to its depletion and pollution. The water recharge due to monsoon rains is less compared to its pumping out, and water table is going down in major part of the north-western India (major wheat growing areas of the country). Though wheat requires only 4-6 irrigations, the consequences of water shortage on production can be substantially high. Taking advantage of the flat electricity charges, farmers continue to irrigate rice fields, even during rainy days leading to decline in ground water levels in the northern India. While in southern Punjab and Haryana, water level and salinity is increasing. Increased water requirements may be anticipated in all regions, which will highlight the importance of irrigation management. The need of the hour is to adopt integrated water management practices, which require judicious use of good quality water and conjunctive use of brackish water. SWI with higher water use efficiency (WUE) can be practiced to mitigate this problem.

Requirement of mitigating the effect of climate change: Based on the climate scenario predicted by the Geophysical Fluid Dynamics Laboratory (GFDL) model, impact of changed climate on wheat production is predicted for various latitude limits $\left(50^{\circ} \mathrm{N}\right.$ latitude to $50^{\circ} \mathrm{S}$ latitude) for the summer and winter seasons. Significant increase in area accompanied by crop yield reductions is expected in the mid to higher latitudes of developed countries. At lower latitudes with increasing temperature, significant area will become unsuitable for wheat production and yield may decline. A net reduction in wheat production is anticipated due to reduction in growth period as a result of increased temperature. It is predicted that with the doubling of $\mathrm{CO}_{2}$, ambient temperature in India would increase by $3{ }^{\circ} \mathrm{C}$ and will affect both the area and productivity of wheat (FAO, 2012). It is also predicted that due to increase in ambient temperature agro-climatic zones may shift towards the pole about $100 \mathrm{~km}$ per degree centigrade rise in average temperature over normal. This may lead to replacement of wheat area by maize or sorghum, and spread of durum wheat in north-western plain zones as they are more tolerant to heat than bread wheat. The strategies under SWI namely proper sowing time, seeding procedures, surface residue retention for temperature moderation and water conservation can help in overcoming the effect of climatic changes.

Targeting the low productivity areas: A sizeable area under wheat cultivation comes from eastern part of India. This area has the potential to increase productivity levels, but as on date the wheat yield in eastern India is quite low (1.30-2.78 t/ha), compared to the average productivity of some leading wheat producers such as Punjab (4.72 t/ha) and Haryana (4.45 t/ha) (Figure 2). Indian Institute of Wheat and Barley Research, Govt. of India conducted a survey during 201011 and tried to identify the reasons of low productivity and slow replacement rate with seeds of new varieties in the farmer's field. The moisture availability period and the moisture range in different states of eastern India vary considerably. As we move from eastern part of Uttar Pradesh to West Bengal, there is an increase in relative humidity and number of humid days. The period from mid-June to September end is humid and the total water availability through rain exceeds the evapotranspiration potential. During rest of the months, there is an acute water deficit. Therefore, there is a need to utilize (or harvest) this additional water for extending the cropping period to winter season as well. Introduc- 
Lalita Rana et al. / J. Appl. \& Nat. Sci. 9 (3): 1453 - 1464 (2017)

Table 1. Area, production and yield of wheat in top 10 wheat producing countries in the world.

\begin{tabular}{llll}
\hline Country & Area (m ha) & Production $(\mathbf{m ~ t})$ & Yield (t/ha) \\
\hline China & 24.1 & 121.7 & 5.05 \\
India & 29.7 & 93.5 & 3.15 \\
United States & 18.3 & 58.0 & 3.17 \\
France & 5.3 & 38.6 & 7.25 \\
Russian Federation & 23.4 & 52.1 & 2.23 \\
Australia & 12.5 & 22.9 & 1.83 \\
Canada & 10.4 & 37.5 & 3.60 \\
Pakistan & 8.7 & 24.2 & 2.79 \\
Germany & 3.1 & 25.0 & 8.00 \\
Turkey & 7.8 & 22.1 & 2.84 \\
World & 218.5 & 713.2 & 3.26 \\
\hline
\end{tabular}

Source: FAO (2014)

Table 2. SWI at a glance.

\begin{tabular}{ll}
\hline Modified practices & Expected outcome \\
\hline Lower seed rate & Higher ratio of tillers to mother seedlings \\
Seed treatment & Increased number of effective tillers hill ${ }^{-1}$ \\
Sowing of seeds at proper spacing & Enhanced panicle length and bold grains \\
Control of water in the crop field & Enhanced yield \\
Weeding / hoeing & Less crop-weed competition \\
\hline
\end{tabular}

Source: Modified from Sheehy et al. (2004)

Table 3. Comparison between traditional wheat cultivation and system of wheat intensification (SWI).

\begin{tabular}{lll}
\hline Particulars & Traditional cultivation & SWI \\
\hline Seed rate & $100-125 \mathrm{~kg} / \mathrm{ha}$ & $20-30 \mathrm{~kg} / \mathrm{ha}$ \\
Seed treatment & Not done & With cow urine and fungicide \\
Sowing & Broadcasting & Line sowing \\
Spacing & No spacing regulation & $20 \mathrm{~cm} \times 20 \mathrm{~cm}$ \\
Weeding/hoeing & Not done & 3 times \\
Length of panicle & $10-11 \mathrm{~cm}$ & $15 \mathrm{~cm}$ \\
No. of grains/panicle & $18-50$ & $60-120$ \\
No. of panicles/hill & Mostly 1-2, Good stand 2-4 & $20-45$ \\
Germination & After a week of sowing & Within 2-3 days of sowing \\
Leaf & Thin; Less leaf area index & Broad; More Leaf area index \\
Stem & Thin & Thick \\
Root & Shallow & Deep (upto 8-10 inches) \\
Irrigation & $2-4$ times & $4-5$ times \\
Yield & $1-2 \mathrm{t} / \mathrm{ha}$ & $3-4 \mathrm{t} / \mathrm{ha}$ \\
\hline
\end{tabular}

Source: ATMA (2008); PRADAN (2012).

Table 4. Economic analysis of wheat production under conventional method and SWI.

\begin{tabular}{|c|c|c|c|c|c|c|c|c|}
\hline \multirow[t]{2}{*}{ Condition } & \multicolumn{4}{|l|}{ Conventional } & \multicolumn{4}{|l|}{ SWI } \\
\hline & $\begin{array}{l}\text { Total cost } \\
\left(\text { Rs. ha }{ }^{-1}\right)\end{array}$ & $\begin{array}{l}\text { Gross return } \\
\left(\text { Rs. } \mathrm{ha}^{-1}\right)\end{array}$ & $\begin{array}{l}\text { Net return } \\
\left(\text { Rs. ha }{ }^{-1}\right)\end{array}$ & $\begin{array}{l}\mathrm{B}: \mathrm{C} \\
\text { ratio }\end{array}$ & $\begin{array}{l}\text { Total cost } \\
\left(\text { Rs. ha }{ }^{-1}\right)\end{array}$ & $\begin{array}{l}\text { Gross return } \\
\left(\text { Rs. } \mathrm{ha}^{-1}\right)\end{array}$ & $\begin{array}{l}\text { Net return } \\
\left(\text { Rs. ha }{ }^{-1}\right)\end{array}$ & $\begin{array}{l}\mathrm{B}: \mathrm{C} \\
\text { ratio }\end{array}$ \\
\hline$\overline{\text { Un-irrigated }}$ & 24,528 & 24,992 & 464 & 1.02 & 35,660 & 63,241 & 27,581 & 1.77 \\
\hline Irrigated & 35,580 & 46,055 & 10,475 & 1.29 & 35,357 & 65,272 & 29,915 & 1.85 \\
\hline Mean & 29,360 & 34,173 & 4,813 & 1.16 & 35,490 & 64,093 & 28,603 & 1.81 \\
\hline
\end{tabular}

Source: Modified from Chopra and Sen (2013)

tion of low water requiring SWI practice may be very effective in those areas (DWR, 2012). No volumetric assessment of water use could be made by SWI farmers; however, managing water to reduce application (alternate wetting and drying instead of continuous flooding) was reported to be the most effective SWI practice for those farmers to adopt.

Temperature is another point of concern as a large area in the eastern India gets hot winds at the grain filling stage of wheat; reducing the yield substantially. Moreover, considerable area in north-eastern India (typically lowlands) is mono-cropped as the soil remains wet for at least one month after rice harvesting. In these areas, SWI method would be effective, where the seeds can be easily germinated with the use of residual soil moisture. Of course, little subsequent irriga- 


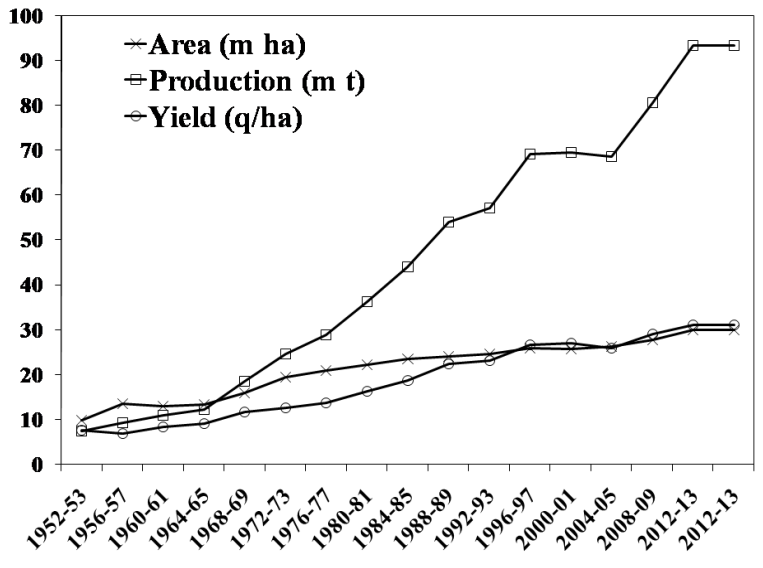

Fig. 1. Trend in wheat acreage, production and yield in India during 1952 through 2013 (Directorate of Economics and Statistics, 2014).

tion may be required to complete its growth cycle.

Production technology for dry lands: Expanding the domain of dryland farming, today rainfed agriculture accounts $55 \%$ (which is totally rain dependent) of the net sown area covering $78 \mathrm{~m}$ ha (NRAA, 2012) and contributes $40 \%$ of food production (Ravindra Chary et al., 2012). The dryland agriculture vis-a-vis rainfed agriculture is influenced by both bio-physical (aberrant weather, and highly degraded soils) and socioeconomic factors (small and marginal farm holdings, resource poor farmers etc.) and their interaction (Ravindra Chary et al., 2012). While developing technologies for dryland areas, these constraints must be kept in mind for efficient and effective utilization of scarce resources available under these stress conditions. Wheat yields can be improved if moisture is conserved through SWI practice (Mishra et al., 2007).

\section{PRACTICE OF SWI IN DIFFERENT PARTS OF THE WORLD}

The cultivation of wheat following the principles of SRI was started few years back worldwide. In Mali, given the heat and wind of the winter season which cause desiccation in plants, direct extrapolation of SWI (transplanting young seedlings) produced poorer results than conventional practice (traditional broadcasting of seed to establish the crop). However, a directseeded version of SWI gave 13\% higher yield with 30 $40 \%$ less labour. In this water-scarce region, the productivity of labour with this method (yield per hour of labour input) went up by $75 \%$, and $25-30 \%$ less water was required. Till date, there are major incentives for farmers who change their practices, and follow SWI (Relkar, 2011).

The Institute for Sustainable Development (ISD) in Addis Ababa, Ethiopia, initiated a number of farmer- participatory evaluations of SRI methods with wheat in 1997. Some initial SWI trial plots in Tigray (Ethiopia) fertilized with compost achieved wheat yields ranging from 3 to $10 \mathrm{t} / \mathrm{ha}$, and thereby there was considerable interest among farmers was noticed. ISD has been evaluating the growing of various rainfed grain crops (rice, wheat, maize) applying compost made from all available biomass (cereal straws / stovers), compared to crop performance with chemical fertilizer. Over seven seasons, yields with compost have surpassed those with inorganic fertilizer by 30\% (Suryanwanshi et al., 2012). Since 2006, Centre for Agro-ecology and Farming Systems of the China Academy of Agricultural Sciences has been working in collaboration with Institute of Yanjiang Agricultural Sciences in Jiangsu Province on adopting SRI ideas into the wheat-rice rotational cropping system (presently about 23.5 million hectares), which is widespread in China and also in the Indo-Gangetic Plains of South-Asia. Average of 3 years data revealed that Jiangsu Province have given combined wheat and rice yields ranging from 13 to 17 $\mathrm{t} / \mathrm{ha}$, which represent $30-70 \%$ increase in yield over conventional method (10 $\mathrm{t} / \mathrm{ha}$ together).

. During 2011-2012, trials were undertaken under Integrated Crop and Water Management Program (ICWMP) at Farmer Field School (FSS) in Sindhuli District (397 above msl) of Central Nepal comparing SWI methods (wheat variety 'Bhirkuti' sown at $20 \mathrm{~cm}$ $\times 20 \mathrm{~cm}$ spacing, hand-weeded and provided with irrigation during CRI and tillering stage) with the traditional broadcast as well as line sowing. In SWI, the tiller numbers and plant height was found higher (25 and $61.4 \mathrm{~cm}$, respectively) compared to the conventional broadcast wheat $(2.6$ and $57.8 \mathrm{~cm})$ and line sown wheat $(3.4$ and $60 \mathrm{~cm})$. Wheat yields were $6.5,5.0$ and $3.7 \mathrm{t} / \mathrm{ha}$ for SWI, line sowing and broadcasting method, respectively. The SWI has also been evaluated since 2010 in Dadeldhura, Doti, Baitadiand and Kailali districts of western Nepal by the NGOs Mercy Corps Nepal and FAYA-Nepal in the farmers' field. The results indicated that SWI methods exhibit 91-100\% more grain yield over traditional practice. Farmers who participated in the demonstration trainings were willing to adopt SWI, given that the yield is increased significantly $(p \leq 0.05)$ to meet their household level food security. Since seed priming, line sowing, gap filling and weeding are some tedious tasks required to perform in SWI, introduction and use of simple tools for seed sowing and weeding are recommended for ensuring wider adoption of SWI in this region.

\section{STATUS OF SWI IN INDIA}

The first trials adapting SRI concepts to wheat was started in Uttarakhand and Himachal Pradesh states of India, under the leadership of Dehradun based NGO People's Science Institute (PSI) during winter 2006-07 with the financial assistance from NABARD (Relkar, 
Lalita Rana et al. / J. Appl. \& Nat. Sci. 9 (3): 1453 - 1464 (2017)
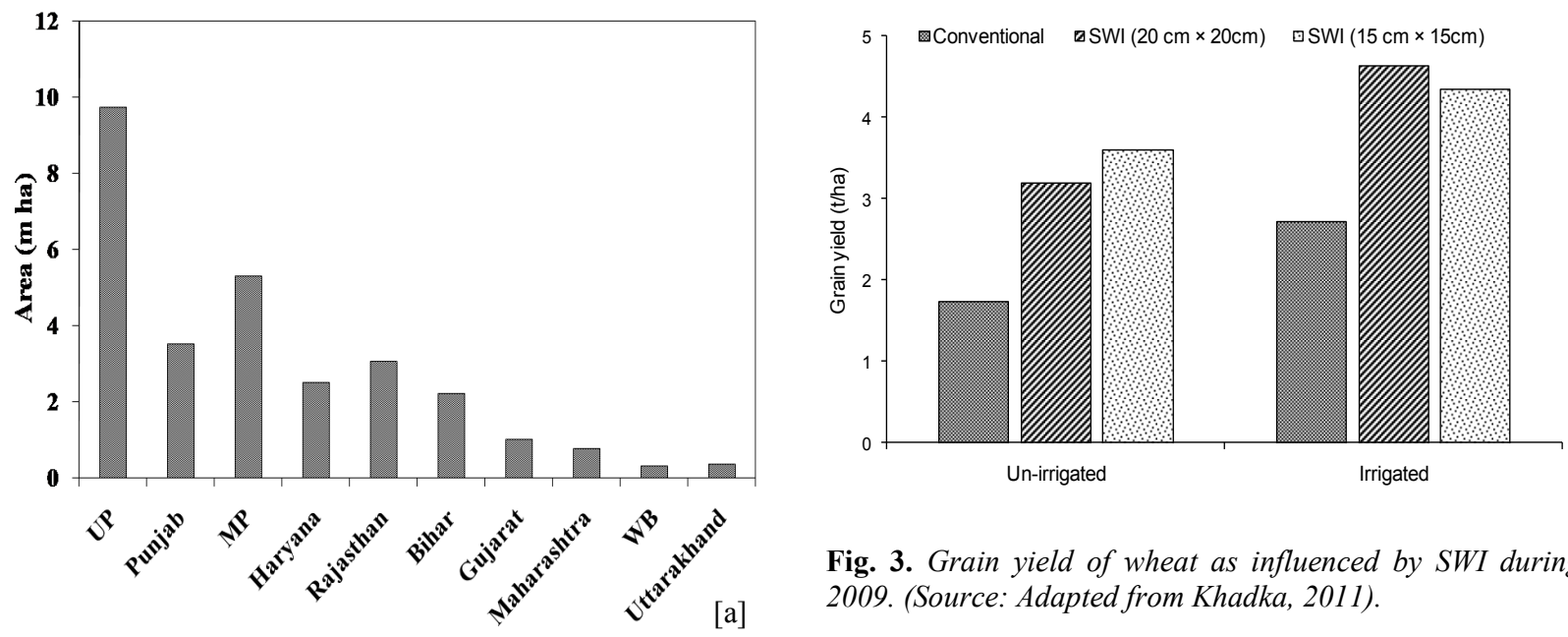

Fig. 3. Grain yield of wheat as influenced by SWI during 2009. (Source: Adapted from Khadka, 2011).
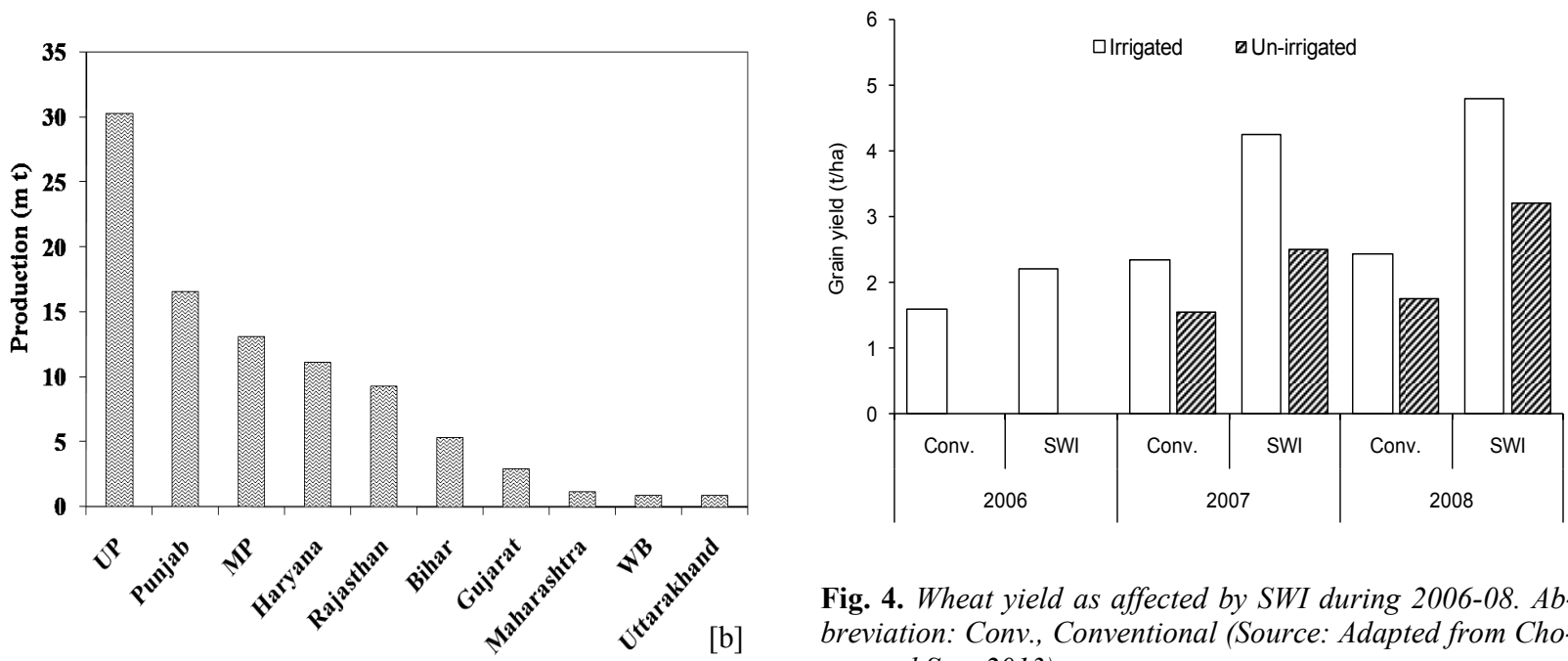

Fig. 4. Wheat yield as affected by SWI during 2006-08. Abbreviation: Conv., Conventional (Source: Adapted from Chopra and Sen, 2013).

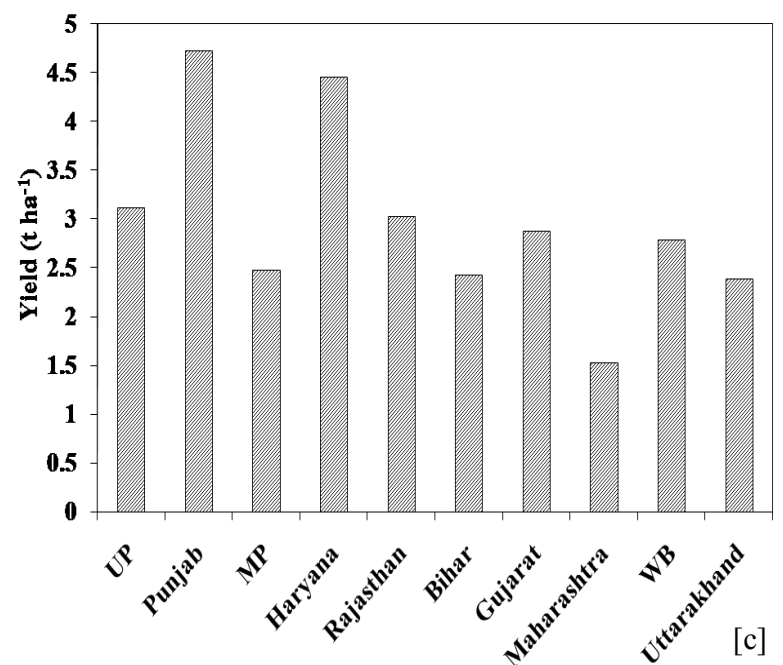

Fig. 2. Area [a] under wheat, and grain production [b] and yield [c] of top 10 States in India (Directorate of Economics and Statistics, 2014).

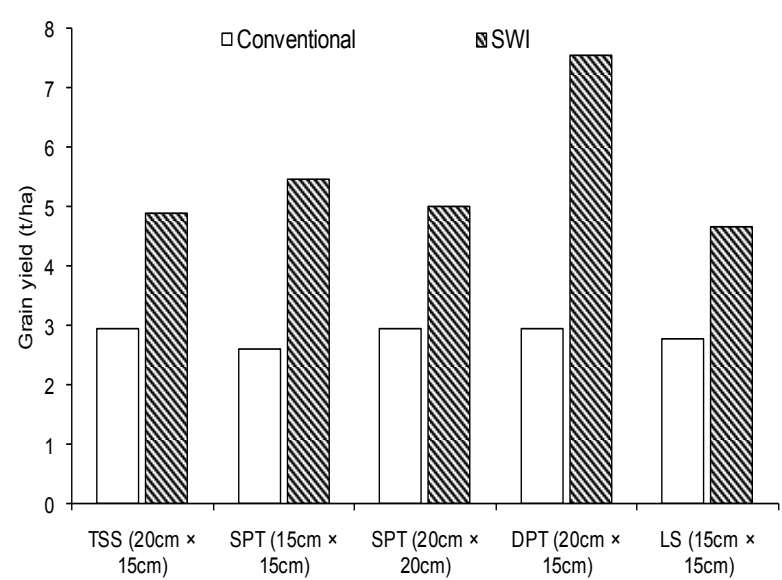

Fig. 5. Grain yield of wheat as influenced by SWI (2009) under irrigated condition. Abbreviations: TSS, Two seed sowing; SPT, Single Plant Transplanting; DPT, Double Plant Transplanting; LS, Line Sowing (Source: Adapted from Chopra and Sen, 2013). 


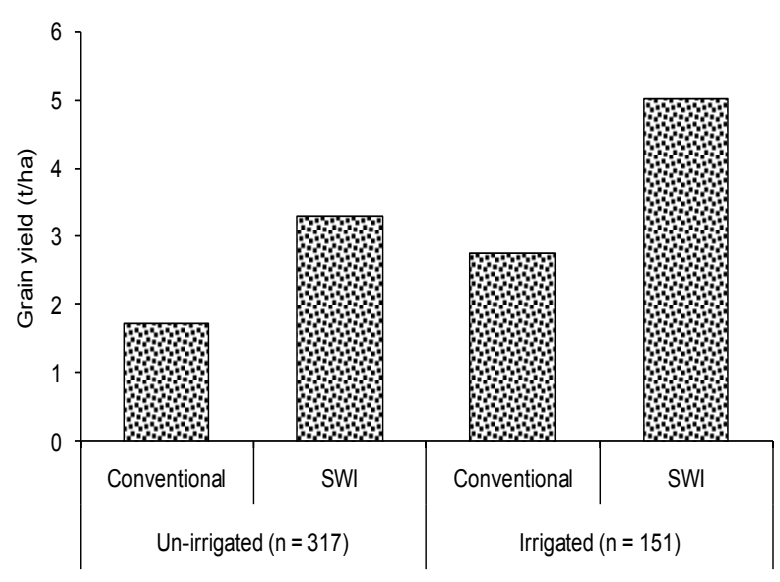

Fig. 6. Grain yield of wheat (as influenced by SWI) grown with and without irrigation in Himachal Pradesh, India during 2008-09 (Source: Adapted from Chopra and Sen, 2013).

2011). These were followed by trials and demonstrations in Madhya Pradesh state at the initiative of another NGO, the Madhya Pradesh Rural Livelihoods Project (MPRLP). Starting with systematic research trials on farmers' fields, SWI practice has now spread in too many Indian states like Bihar, Chattisgarh, Madhya Pradesh, Odisha, Punjab and Uttar Pradesh through the efforts of PSI and other voluntary organizations (Chopra and Sen, 2013). Recently, the NGO, Jeevika has been getting excellent results in Bihar state, and their report says that 30,000 farmers have been using SWI methods since 2009-2010 (PRADAN, 2012).

Evidence is accumulated by the Scientists at People's Science Institute (PSI) that in northern India (Dehradun, Himachal Pradesh and Uttarakhand) there is no change in management practices as large farmers are moving from anaerobic to aerobic soil conditions with SWI. However, PSI evaluators (from Dehradun) also found that the best use of wider spacing and other SWI-inspired practices, wheat cultivars produced more grain and straw yield (28-40 and 18\%, respectively) compared to the standard broadcasting methods. According to them it is expected to reduce labour costs with SWI, including use of seed drill and weeder. Govt. of Bihar has also taken an initiative to popularize the SWI technique in Bihar (Gaya, Purnia and Muzaffarpur districts) under Bihar Rural Livelihoods Project (http://www.brlp.in).

\section{PRODUCTION TECHNOLOGY FOR SWI}

Similar to that of SRI technology, SWI also requires quality seeds as well as special agronomic management practices. Details of wheat cultivation with SWI technology has given below.

Land preparation: Prior to final land preparation (1520 days ahead) $2.0 \mathrm{t}$ FYM or $0.4 \mathrm{t}$ of vermin-compost per acre of land should be applied. If the soil does not have appropriate moisture, irrigate before ploughing.
Before the last ploughing, broadcast $27 \mathrm{~kg}$ DAP (4.86 $\mathrm{kg} \mathrm{N}$ and $12.42 \mathrm{~kg} \mathrm{P}_{2} \mathrm{O}_{5}$ ) and $13.5 \mathrm{~kg}$ potash per acre of land. However, the doses of nutrients are highly variable depending upon the yield target. The fertilizer (both organic and inorganic) requirement during land preparation and top dressing can be determined using the nutrient decision support systems such as "Nutrient Expert $^{\circledR}$ ", (Majumder et al., 2014).

Selection of seed: Only healthy seeds of right variety suitable for a particular locality should be selected for sowing. There should not be any mixture of seeds of other varieties of weeds. Always certified seed, purchased from a reliable source (Govt. Farms, State Agricultural University, State Seed Corporation Ltd., Krishi Vigyan Kendra and Private Seed Companies) should be used.

Seed treatment: The following inputs are required:

Improved seed: $10 \mathrm{~kg}$

Warm water $\left(60^{\circ} \mathrm{C}\right): 20$ liters

Vermi-compost: $5 \mathrm{~kg}$

Gur (Molasses): $4 \mathrm{~kg}$

Cow urine: 4 liters

Bavistin: $20 \mathrm{~g}$

Seed treatment process:

According to PRADAN (2012) the following steps are to be taken sequentially.

i) Separate foreign materials from $10 \mathrm{~kg}$ seed, if any.

ii) Take 20 liters of warm water (up to $60^{\circ} \mathrm{C}$ ) in a vessel.

iii) Put the seed material in the warm water.

iv) Remove the floating seeds (chaffy in nature) from the warm water. Add $5 \mathrm{~kg}$ vermin-compost, $4 \mathrm{~kg}$ gur and 4 liters of cow urine, and keep the mixture for 8 hours.

v) Separate the seed mixture from the solution, and then sieving it through a cotton cloth after 8 hours.

vi) Add $20 \mathrm{~g}$ Bavistin to the seed mixture and keep this for 12 hours in a wet jute bag for germination and for subsequent sowing.

Time of seed sowing: It has a marked influence on the yield of wheat. The time of sowing varies widely over the wheat growing areas. It depends mostly on soil temperature, irrigation, facilities and duration of wheat varieties.

Method of seed sowing: Moisture availability in soil is required when the germinated seeds are sown. Two seeds/ hill are normally sown and spacing is maintained at $20 \mathrm{~cm}$. If the germination is not uniform then gap filling should be done within 7 days.

Irrigation: Phase-wise irrigation management should be as follows-

i) First irrigation is done 15 days after sowing (DAS) to trigger root initiation. Otherwise, unavailability of moisture in soil will prevent root initiation.

ii) Second irrigation is given at $25 \mathrm{DAS}$, results in emerging more number of tillers.

iii) Third irrigation is given at 35-40 DAS.

iv) Subsequent irrigations are given at 60, 80 and 100 
DAS, depending on soil and climatic conditions.

During the flowering and grain-filling stage, appropriate moisture should be available in the soil.

Manure and fertilizer: Phase-wise manure and fertilizer application should be as follows-

i) After the first and third irrigation, manure and fertilizer are applied.

ii) After the first irrigation, $4 \mathrm{q}$ of vermi-compost and $40 \mathrm{~kg}$ of urea per acre are applied.

iii) After the third irrigation, $15 \mathrm{~kg}$ urea and $13 \mathrm{~kg}$ potash/acre are applied.

Once again, it is to be remembered that the nutrient requirement is yield dependent and therefore, will vary accordingly.

Weeding: Phase-wise weeding should be followed which would help in producing more numbers of tiller/ plant with greater vigor.

i) First weeding is done 2-3 days after irrigation.

ii) After the each irrigation, hoeing and weeding should be done to loosen the soil and to make the wheat field weed-free.

The loosening of soil results in better aeration for the root zone and increases the root length by letting them to take more moisture and nutrient from the soil.

Few successful case studies in India: Results of wheat cultivation following SWI principles have been depicted here under. Khadka (2013) reported that wheat cultivars 'HD-2329' and 'PBW 396' both performed well under SWI as compared to conventional method (broadcasting) in Dehradun and Himachal Pradesh of India. Square planting direction was followed and cultivar 'HD-2329' gave higher grain yield (2.3 t/ ha) with $15 \mathrm{~cm} \times 15 \mathrm{~cm}$ spacing while 'PBW 396' produced higher yield (2.3 and $7.6 \mathrm{t} / \mathrm{ha}$ for grain and straw yield respectively) at $20 \mathrm{~cm} \times 20 \mathrm{~cm}$ spacing. All the yield attributing characters of both the cultivars showed similar trend to that of yield. Findings on SWI from Himachal Pradesh also exhibited higher grain (4.3 $\mathrm{t} / \mathrm{ha})$ and straw yield $(7.4 \mathrm{t} / \mathrm{ha})$ of wheat, accounting 53 and $60 \%$ more than conventional practice, respectively.

In un-irrigated situation, plants with closer spacing $(15 \mathrm{~cm} \times 15 \mathrm{~cm})$ have higher yield (grain and straw) than wider spacing $(20 \mathrm{~cm} \times 20 \mathrm{~cm})$ while under irrigated situation the wider spacing was better for wheat plant for higher yield attributes and yield of wheat (Fig. 3). System of crop intensification (SCI) trials during three consecutive years (2006, 2007 and 2008) with wheat at PSI-Dehradun revealed that SCI was superior to conventional method (Fig. 4). Crop gave higher yield under irrigated situation over un-irrigated condition and there was a gradual increase in wheat yield over the years $(2.2,4.25$ and $4.8 \mathrm{t} / \mathrm{ha}$ in 2006, 2007 and 2008 respectively) with SCI under irrigated situation (Chopra and Sen, 2013).

In another experiment during 2009 in Dehradun (Uttarakhand), crop cutting results of SWI under irrigated condition revealed that direct seeding was less effective for wheat cultivation as compared to SWI. Wheat crop when transplanted gave higher yield (71 to $158 \%$ higher than seed sowing) with greater economic feasibility. Double plant transplanting was more effective than single plant transplanting (Fig. 5). Chopra and Sen (2013) demonstrated that even when transplanted with single seedling, crop gave higher yield attributes as well as yield with wider spacing $(20 \mathrm{~cm} \times$ $20 \mathrm{~cm})$ over closer spacing $(15 \mathrm{~cm} \times 15 \mathrm{~cm})$.

In Himachal Pradesh trials (during 2008-09), SWI technology showed similar trend to that of earlier studies (Chopra and Sen, 2013). SWI crop gave higher grain yield than broadcasting method (conventional method) under both un-irrigated (91\% over conventional) and irrigated ( $82 \%$ over conventional) condition (Fig. 6). Based on farmers' level data (Sample Size: 266 farmers), it was also revealed that economically SWI was better than conventional method both in terms of net return and $\mathrm{B}: \mathrm{C}$ ratio (Table 4).

Why is yields better with SWI?: To understand this, we need to understand the root structure of the plant and their functions.

i) Seminal roots are initiated after the germination of seeds and move downwards into the soil in search of nutrients and water. If the soil is not moist and becomes hard, then it becomes difficult for the roots to go very deep into the soil.

ii) Crown roots which develop about 20 days after sowing (DAS) spread out horizontally for nutrients and water. If the soil is hard, the young plants cannot spread out their root network for acquiring water and nutrients. This stunting effect on plants induced due to hard soil is known as the Bonsai Effect.

iii) Sometimes the roots are destroyed with the attack of a fungal pathogen named Pythium (Masle and Passioura, 1987).

\section{ADVANTAGE OF SWI}

SWI practice constructively reduces the capital, fertilizer, labour and water inputs while increasing crop yields. Further, this method promotes more abundance, diversity and activity of soil biota in and around rhizosphere zone of the plant. These modified practices with reduced inputs, supported by good aeration and organic matter for the soil, lead to general improvement of crop productivity.

Direct seeded SWI performed remarkably better than transplanted SWI. Reports also revealed that direct seeded SWI performed remarkably better than transplanted SWI due to the following reasons.

i) Wheat seedlings at the two leaves stage were far more fragile and their stems were much weaker for transplanting.

ii) Transplanting slowed crop development as compared to direct seeding.

iii) Direct- seeded plants grew faster and more vigorously. 
iv) Yield parameters namely number of tillers/plant, panicles plant, percent fertile tillers, panicle length, and number of grains/panicle were substantially lower under transplanted SWI compared to direct seeded SWI.

v) Crop development and subsequent ripening of the panicles under transplanted SWI were not as uniform as direct seeded treatment. Even some of the smaller and younger panicles were not fully ripe at harvest.

The above points clearly narrate the merit of direct seeded SWI practice. But the only superior result for transplanted SWI was the improved survival rate (91\%) when compared with direct seeded SWI (78\%).

Knowledge for belief: The system of wheat intensification (SWI) method appears to a viable alternative for wheat cultivation under water-stress conditions, besides assuring food security of poor, marginal and landless farmers of wheat growing areas. An estimate says that increment of wheat yield with complete SWI technique can be sufficient to guarantee food for a 6member household for more than 6 months @ 4 kg/ day consumption (PRADAN, 2012).

Opportunity: i) Scaling up of SWI across various parts of the country.

ii) Inclusion of system of wheat intensification (SWI) under the National Food Security Mission (NFSM) for attaining better food security for the poor.

iii) Research to develop seed drill for sowing of wheat seeds on large scale, and other equipments such as cono-weeders, power-weeders etc (PRADAN, 2012).

Issues and future strategies: In India, the wheat programme has been very vibrant during the last four decades, as indicated by the production, productivity and other achievements. But there is no room for complacency and the programme needs to be more responsive to the new emerging issues under the present scenario. Several studies (Satyanarayana et al. 2007; Chopra and Sen, 2013; Khadka,2013) reported that direct seeded SWI showed a $13 \%$ yield increase over the control, but yields under the transplanted treatment were $29 \%$ less than the control. Increase of wheat yield by $13 \%$ is not very high. There is much potential for further yield increase by reducing plant mortality in some wheat growing pockets, and also by reducing plant spacing, maintaining optimal time for sowing, and applying higher amounts of nutrients. Optimal plant spacing has not yet standardized, and for this more experiments on spacing (Plant to Plant and Row to Row distance) needs to be carried out. Spacing of $25 \mathrm{~cm}$ between the lines could be maintained, or slightly reduced to 20 $\mathrm{cm}$, to allow the use of the cono-weeder. With the reduction of plant spacing, the number of plants $\mathrm{m}^{-2}$ will increase. In combination with the observed higher tillering rate, the high percentage of fertile tillers, the larger panicles with a larger number of grains, and a higher 1000-grain weight, there could be much potential for significant yield increases compared to nor- mally grown crop.

Policy making: i) Networking among the stakeholders must be formed and/or strengthened.

ii) Farmers should be given flexibility in adopting the SWI practices.

iii) Reasons for drop-outs from SWI cultivation must be analysed, and effective steps like counselling should be taken to prevent and/or bring back the drop-outs.

iv) Participatory SWI movement is to be promoted.

v) As many 'Master Trainers' as possible must be trained in command areas where farmers do not have control over water release. Suitable strategies must be worked out to promote SWI under such situations in successful manner.

vi) Proper nutrient management has had little attention so far, simply recommending application of as much organic matter as possible. More evaluation and mobilization of organic matter should be provided for to ensure maximizing productivity and sustainability under SWI.

vii) In water management, possibilities to adopt microirrigation should be pursued.

viii) Overall, soil health must be attended to improve and sustain.

\section{Conclusion}

Summarily, it can be said that SWI has shown superior performance on all measured growth parameters, yield attributes and grain yield compared to conventional method. Farmers from different parts of the world are convinced with the encouraging results of SWI, as this method performs equally well both in favourable and unfavourable (climatic stress) situations. The SWI technology has already established its strength in terms of multiple benefits like enhanced productivity per unit land, water and other inputs with higher economic gain. However, more detail study is needed on various agronomic and other bio-physical changes in the plants under SWI method. Finally, more skill-orineted training for the SWI farmers is required to build up their confidence.

\section{REFERENCES}

Anjuman, T. and Bajwa, R. (2010). Competition losses caused by Rumex dentatus L. and Chenopodium album L. in wheat (Triticum aestivum L.). The Philippine Agric. Scientist., 93: 14-17.

ATMA. (2008). Assessment, Refinement and Validation of Technology through System of Wheat Intensification (SWI) in Nalanda: Final Report. Agriculture Technology Management Agency (ATMA), Nalanda, with assistance of PRADAN, Nalanda, Bihar, INDIA. Available at URL: krishi.bih.nic.in (Accessed $14^{\text {th }}$ April, 2015).

Chopra, R. and Sen, D. (2013). Golden wheat becomes more Golden - Extending SRI to wheat. LEISA India 15: 3032.

Choudhary, R.L. and Behera, U.K. (2013). Effect of sequential tillage practices and $\mathrm{N}$ levels on energy relations 
and use-efficiencies of irrigation water and $\mathrm{N}$ in maize (Zea mays) - wheat (Triticum aestivum) cropping system. Indian J Agron., 58: 27-34.

Dhar, S., Barah, B.C. and Vyas, A.K. (2014). Comparative performance of System of Wheat Intensification (SWI) and other methods of wheat cultivation in north western plain zone of India. In: International SRI Research seminar on recent Changes in Rice Production and Rural Livelihoods: New Insights on the System of Rice Intensification (SRI) as a Socio-Technical Movement in India. Indian Agricultural Research Institute, New Delhi. Available at URL: http://www.sri-india.net/ event2014/research.htm\#Abstract 7 (Accessed 12 March, 2015).

Dhar, S., Barah, B.C., Vyas, A.K. and Uphoff, N.T. (2016) Comparing System of Wheat Intensification (SWI) with standard recommended practices in the northwestern plain zone of India. Archives Agron Soil Sci., 62(7): 994 -1006 .

Directorate of Economics and Statistics. (2014). Agricultural Statistics at a glance 2014. Department of Agriculture and Cooperation, Ministry of Agriculture, Govt. of India.

Dobermann, A. (2004). A critical assessment of the system of rice intensification (SRI). Agric. Sys., 79: 261-281.

Dutta, S., Majumder, K., Satyanarayan, T. and Singh, S.K. (2015). 4R nutrient stewardship - a way forward towards sustainable agriculture. SATSA Mukhopatra, Annual Technical Issue., 19: 19-35.

DWR. (2012). Progress Report, All India Coordinated Wheat \& Barley Improvement Project, Directorate of Wheat Research, Karnal, 4.

FAO. (2012). FAO Statistical Yearbook 2012: World Food and Agriculture. Available at URL: http://www.fao.org (Accessed 12 ${ }^{\text {th }}$ April, 2015).

FAO. (2014). Available at URL: http://faostat.fao.org (Accessed on: $21^{\text {st }}$ April, 2015).

Gupta, M., Bali, A.S., Kour, S., Bharat, R. and Bazaya, B.R. (2011). Effect of tillage and nutrient management on resource conservation and productivity of wheat (Triticum aestivum). Indian J Agron., 56: 116-120.

Johnston, A.E. (1994). The Rothamsted classical experiments. In Long-term Experiments in Agricultural and Ecological Sciences, eds. R.A. Leigh and A. E. Johnston, Wallingford, UK: CAB International, pp: 9-37.

Kabeya, M.J. and Shankar, A.G.(2013). Effect of different levels of zinc on growth and uptake ability in rice zinc contrast lines (Oryza Sativa L.). Asian J. Plant Sci. Res., 3: $112-116$.

Kaur, R., Mahey, R.K. and Kingra, P.K. (2012). Effect of population density of Phalaris minor on production potential of wheat (Triticum aestivum). Indian $J$. Agron., 57: 157-161.

Khadka, R.B. (2011). System of crop intensification: practice and experience, Forum for Awareness and youth activity Nepal, Dhagadhi, Kailali.

Khadka, R.B. (2013). System of Wheat Intensification (SWI) - A New Technology for Wheat Intensification Practiced in Kailali Nepal. Presentation by Ram B. Khadka,Programme Coordinator, European Union Food Facility, FAYA- Nepal, Dhangadhi, Kailali, Nepal. 10 slides. Available at URL:http://www.slideshare.net/ SRI.CORNELL/1304-system-of-wheat-intensificationin-kailali-nepal-swi (Accessed $21^{\text {th }}$ January, 2015).
Li, X., Xu, X. and Li, H. (2005). A socio-economic assessment of the system of rice intensification (SRI): a case study from Xiushang village, Jianyang county, Sichuan province. Report for the Centre for Integrated Agricultural Development, China Agricultural University, Beijing.

Majumder, K., Satyanarayan, T., Dutta, S., Pampolino, M., Jat, M.L., Shahi, V., Iftekar, W., Govil, V. and Singh, V.K. (2014). On-farm performance of 'Nutrient Expert' for maize: fertilizer recommendation, yield and nutrient use efficiency. Better Crops South-Asia, 8: 24-27.

Masle J. and Passioura, J.B. (1987). The effect of soil strength on the growth of young wheat plants. Australian J. Plant Physiol., 14: 643-656.

McDonald, A.J., Hobbs, P.R. and Riha, S.J. (2006). Does this system of rice intensification outperform conventional best management? A synopsis of the empirical record. Field Crops Res., 96: 31-36.

Meena, B.L. and Singh,R.K.(2013). Response of wheat (Triticum aestivum) to rice (Oryza sativa) residue and weed management practices. Indian J. Agron., 58: 521524.

Mishra, B., Chatrath, R., Mohan, D., Saharan, M. S. and Tyagi, B.S. (2007). DWR Perspective Plan: Vision 2025. Directorate of Wheat Research, Karnal, India, 1415.

Mukherjee, D. (2012). Effect of different sowing dates on growth and yield of wheat (Triticum aestivum) cultivars under mid hill situation of West Bengal. Indian $J$. Agron., 57: 152-156.

NRAA. (2012). Prioritization of rainfed areas in India.Study Report 4, National Rainfed Area Authority, New Delhi, India, 100.

PRADAN. (2012). Cultivating wheat with SRI Principles: A manual. System of Rice Intensification website.

Ravindra Chary, G., Venkateswarlu, B., Sharma, S.K., Mishra, J.S., Rana, D.S. and Kute, G. (2012). Agronomic research in dryland farming in India: An overview. Indian J. Agron. ( $3^{\text {rd }}$ IAC: Special Issue), 157-167.

Relkar, P.M. (2011). System of Wheat Intensification (SWI).Technical Digest, 13: 11-15.

Satyanarayana, A., Thiyagarajan, T.M., Uphoff, N. (2007. Opportunities for water saving with higher yield from the system of rice intensification. Irrig. Sci. 25: 99-115.

Sheehy, J.E., Peng, S., Dobermann, A., Mitcheli, P.L., Ferrer, A., Yang, J., Zou, Y., Zhong, X. and Huang, J. (2004). Fantastic yields in the system of rice intensification: fact of fallacy? Field Crops Res., 88: 1-8.

Singh, N., Kumar, D., Thenua, O.V.S. and Tyagi, V.K. (2012). Influence of spacing and weed management on rice (Oryza sativa) varieties under system of rice intensification. Indian J. Agron., 57: 138-142.

Sinha, S.K. and Talati, J. (2007). Productivity impacts of the system of rice intensification (SRI): A case study in West Bengal, India. Agric. Water Manage., 87: 55-60.

Styger, E. and Ibrahim, H. (2009). The System of Wheat Intensification (SWI): Initial Test by Farmers in Goundam and Dire, Timbuktu, Mali, Africare, Mali, Bamako Available at URL:http://ciifad.cornell.edu/sri/countries/ mali/MaliSWIrpt071309.pdf (Accessed 23th January, 2015).

Styglinger, M. (2011). Innovation of the Week: Researchers Find Farmers Applying Rice Innovations to their Wheat Crops. Australian J. Plant Physiol., 14: 643-656. 
Suryawanshi, P.K., Patel, J.B. and Deore, S.M. (2012). System of Wheat Intensification (SWI): New trend of wheat cultivation. Lambert Academic Publishing, Saarbruken, Germany, pp: 120.

Uphoff, N. (2006). The development of the System of Rice Intensification. Participatory research and development for sustainable agriculture and rural development, 3, 119-125.
Uphoff, N., Kassam, A. and Harwood, R. (2011). SRI as a methodology for raising crop and water productivity: productive adaptations in rice agronomy and irrigation water management. Paddy Water Environ., 9: 3-11.

Xu, H.L., Xu, Q., Qin, F.F., Liu, Q. and Lin, S. (2011). Grain yield and leaf photosynthesis in transplanted winter wheat. J Food Agric. Environ., 9(2): 328-334. 